\title{
Titanium and iron analysis in eye shadows and blushes by energy-dispersive $X$-ray fluorescence technique
}

\section{Análise de titânio e ferro em sombras e blushes por fluorescência de raios $X$ por dispersão em energia}

\author{
Diego de Dio Ferreira ${ }^{1}$; Carlos Roberto Appoloni ${ }^{2}$
}

\begin{abstract}
The objective of this work was to estimate titanium and iron superficial density in eye shadows and blushes employing energy dispersive X-ray fluorescence methodology and determine other elements present in eye shadows and blushes samples of three different trademarks. A portable EDXRF system was used to analyze 36 eye shadows samples and 7 blushes samples. Quantification was performed using calibration curves with titanium and iron standards, $47,9 \mu \mathrm{g} / \mathrm{cm}^{2}$ superficial density, thin film type, deposited on polycarbonate membranes, both from MicroMatter Inc. Titanium and iron superficial density were measured in all the analyzed samples, calculated the ratio titanium/iron and detected other elements in the samples beyond titanium and iron.
\end{abstract}

Keywords: Eye Shadow. Blush. X-Ray Fluorescence. Titanium. Iron.

\section{Resumo}

O objetivo desse trabalho foi estimar a densidade superficial de titânio e ferro em sombras e blushes utilizando Fluorescência de Raios X por Dispersão em Energia e determiner outros elementos presentes em amostras de sombras e blushes de três marcas diferentes. Um sistema portátil de EDXRF foi utilizado para analisar 36 amostras de sombras e 7 amostras de blushes. A quantificação foi por meio de curvas com padrões de titânio e ferro, com densidade superficial de $47,9 \mu \mathrm{g} / \mathrm{cm}^{2}$, do tipo filme fino, depositados em membranas de policarbonato, ambas da MicroMatter Inc. A densidade superficial do titânio e do ferro foi medida em todas as amostras analisadas, a razão titânio/ferro foi calculada e outros elementos, além desses, foram determinados. Palavras-chave: Sombra. Blush. Fluorescência de Raios X. Titânio. Ferro.

\footnotetext{
${ }^{1}$ Discente, Curso de Doutorado, Programa de Pós-Graduação em Física, UEL, Londrina, Pr, Brasil; E-mail: dio@uel.br

${ }^{2}$ Prof. Dr. Departamento de Física, UEL, Londrina, Pr, Brasil; E-mail: appoloni@uel.br
} 


\section{Introduction}

Painting the face is a habit since prehistoric times. Neanderthal man painted his face with reds, browns, and yellows derived from clay, mud, and arsenic. The use of cosmetics, fragrances, and personal care products can be traced back to ancient times as early as Egyptian, Greek, and Roman eras (KUMAR, 2005). The Egyptians painted their eyes to avoid direct contemplation of the sun god for such they used animal and vegetable fat, beeswax, honey and milk to prepare skin creams (ATZ, 2008). Since the Ancient Egypt, beauty products have been used by all social classes. In 2001, makeup products constituted roughly $18 \%$ of total global market for Cosmetics, Toiletry, and Fragrance.

Eye shadows are found as powder, cream, emulsion, sticks and crayon. The basic composition of the powder is talc/kaolin, organic and inorganic pigments and binders The most used inorganic pigments in eye shadows are, in general, oxides of metals. These compounds grant basic colors, e.g., iron oxide black and carbon black for black eye shadow, ultramarine (sodium aluminum sulpho silicate) and Prussian blue (potassium ferrocyanide) for blue eye shadow, chromium oxide for green eye shadow, iron oxide brown for brown eye shadow, iron oxide yellow for yellow eye shadow and carmine for red eye shadow. Titanium dioxide and zinc oxide are used to produce brighter tones (ATZ, 2008). These pigments are not always pure, and may contain impurities such as $\mathrm{Ni}, \mathrm{Cr}, \mathrm{Cd}, \mathrm{Pb}, \mathrm{As}$ and $\mathrm{Hg}$.

The amount of $\mathrm{Ni}, \mathrm{Cr}, \mathrm{Cd}, \mathrm{Pb}, \mathrm{As}$ and $\mathrm{Hg}$ should be lower than $5 \mathrm{ppm}$ and for an even greater safety, the ultimate target level should be 1 ppm (BASKETTER et al., 2003; CORAZZA, M. et al., 2009).

According to ANVISA (Brazilian National Health Surveillance Agency), the compounds used in cosmetic formulations for the eye area must follow specifications of identity and purity established by international organizations, such as FDA (Food and Drug Administration). Inorganic pigments are allowed, provided that they are water-insoluble. Eye shadows are classified by ANVISA as minimum risk products about what regards the health risks. Specific indications are not obligatory in these product's labels, as well as safety and efficacy proof, care information, usage mode and restrictions (ANVISA, 2000).

It is important to emphasize that there is no specific legislation concerning toxic elements' residues such as As, $\mathrm{Cd}, \mathrm{Co}, \mathrm{Ni}, \mathrm{Pb}$ and $\mathrm{Hg}$ in eye shadow, neither in Brazil nor abroad. Some chromium and copper compounds may be safely used in coloring cosmetics, generally including cos- metics intended for use in the area of the eye, in amounts consistent with good manufacturing practice (U.S. GOVERNMENT, 2014).

The objective of this work was to estimate titanium and iron superficial density in eye shadows and blushes employing energy dispersive X-ray fluorescence methodology and determine other elements present in eye shadows and blushes samples of three different trademarks.

\section{Materials and methods}

\section{EDXRF instrumentation}

The EDXRF measurement system is a homemade portable one, composed of a Si-PIN detector (149 keV resolution for $5.9 \mathrm{keV}$ energy of $\mathrm{Mn} \mathrm{K} \alpha$, with $12.7 \mu \mathrm{m}$ Be window), model XR-100CR (AMPTEK, 1998), high voltage source with amplifier, model PX2CR, multichannel analyzer model MCA8000A and a notebook for data acquisition and storage. Sample excitation was accomplished with a mini X-ray tube with Ag target (4 W, 10-40 $\mathrm{kV}, 0-100 \mu \mathrm{A}$, and focus diameter of $5 \mathrm{~mm}$ ) (MOXTEK, 2003). The whole system is portable and can be used for measurements at the sampling place. The measurement geometry is $45^{\circ} \times 45^{\circ}$ and the sample is positioned at 10 $\mathrm{mm}$ distance from $\mathrm{X}$-ray tube/detector.

\section{Sampling}

Thirty-six eye shadows samples and 7 blushes samples from 3 different trademarks cases, found at popular stores, were measured and shown in figure 1. Titanium and iron certified standards from MicroMatter Inc., with surface density of $47.9 \mu \mathrm{g} / \mathrm{cm}^{2}$, thin film type and deposited on polycarbonate membranes, were also measured.

The samples and standards were measured without any preparation, in other words, they were measured as found commercially, simply taking a small portion which was swabbed on a paper sheet and covered with a polyester film (Mylar), proper for X-ray fluorescence measurements.

Each sample and standard were measured in triplicate. The measurement conditions of the EDXRF equipment were $25 \mathrm{kV}, 10 \mu \mathrm{A}, 50 \mu \mathrm{m}$ thickness Ag filter at the Xray tube output, $\mathrm{Ag}$ collimator with $3 \mathrm{~mm}$ diameter at the detector entrance and $500 \mathrm{~s}$ live time of measurement time. 
Figure 1: Eye shadows and blushes samples from trademark A, B and C. Samples named with a "b" are blushes.
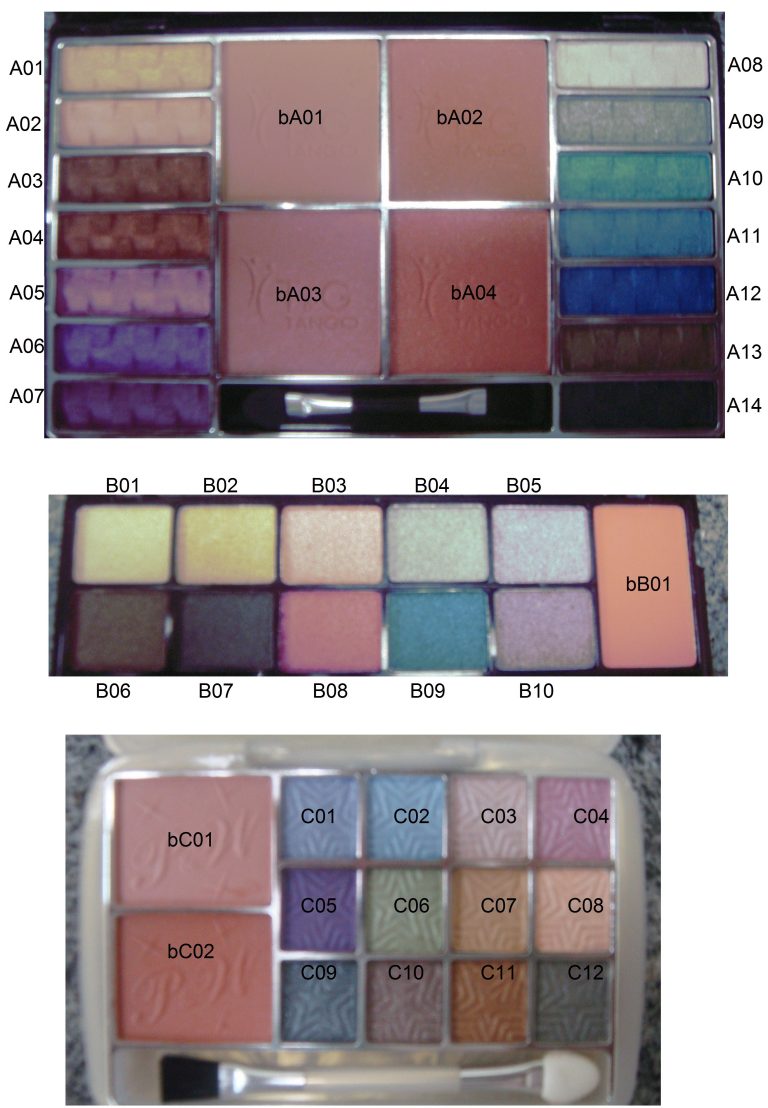

Source: The Author.

\section{Quantitative EDXRF analysis}

Fundamental parameters equation for infinitely thick samples was used for quantification (VAN GRIEKEN and MARKOWICZ, 2002), as all samples had superficial density over $0.37 \mathrm{gcm}^{-1}$ :

$$
I_{i}=C_{i} S_{i} A
$$

where $I_{i}$ represents the net intensity of the characteristic $\mathrm{X}$-rays (cps), $C_{i}$ represents the element concentration (\% of mass), $S_{i}$, the elementary sensitivity (cps/\%mass) of the analyzed element and $A$ is a non-dimensional factor that considers the matrix absorption for the characteristic X-rays.

The titanium and iron standards were measured with the Portable EDXRF system and the calibration curves were fitted using the software Origin 8.0. The sensitivity curves obtained for titanium and iron employing MicroMatter Inc. standards were:

$$
D_{T i}=3.2142 I_{T i}
$$

$$
D_{F e}=1.1207 I_{F e}
$$

where $D$ is the surface density (in $\mu \mathrm{g} / \mathrm{cm}^{2}$ ) and $I$ is the intensity (cps).

\section{Results and discussions}

As the standard's matrix density is similar to the analyzed samples, it was not necessary to determine the absorption factor. Figures 2 and 3 show illustrative spectra of a sample and a standard, respectively, showing good identification of the elemental composition.

Figure 2: Eye shadow sample A02 spectrum with both titanium and iron $\mathrm{K} \alpha$ and $\mathrm{K} \beta$ peaks intensities in counts per second. The silver $\mathrm{L} \alpha$ peak is due to the Ag target of the X-ray tube, and the argon $\mathrm{K} \alpha$ peak is due to the presence of argon in the air.

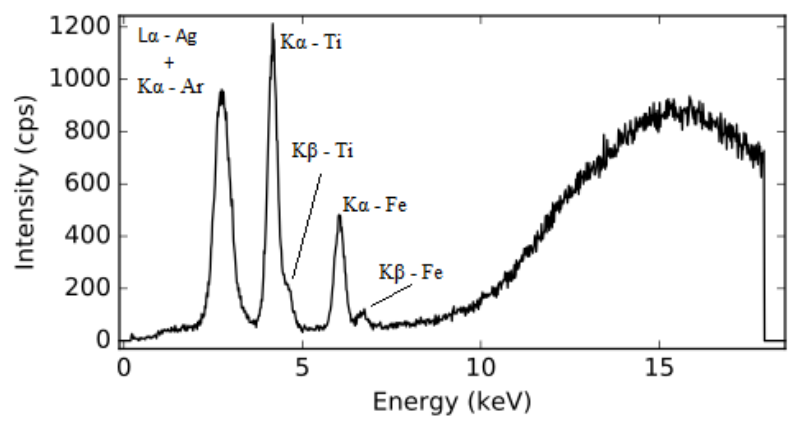

Source: The author.

Figure 3: MicroMatter Inc. titanium standard spectrum with titanium $\mathrm{K} \alpha$ and $\mathrm{K} \beta$ peaks intensities in counts per second. The silver $L \alpha$ peak is due to the Ag target of the $\mathrm{X}$-ray tube, and the argon $\mathrm{K} \alpha$ peak is due to the presence of argon in the air.

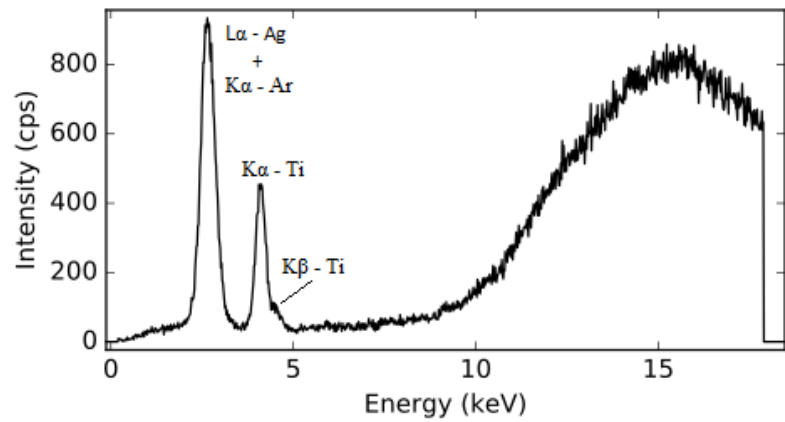

Source: The author.

The values for titanium and iron surface density of the eye shadows samples, calculated through equations (2) and (3), are shown in table 1.

Table 1 shows the presence of titanium and iron in every sample, however with a great variability in the surface density for both titanium and iron. The greatest surface density for titanium was found in sample A02, 123.41 $\mu \mathrm{g} / \mathrm{cm}^{2}$, beige colored, where titanium is used to produce lighter shades (ATZ, 2008). The greatest surface density for iron was found in sample A14, $198.16 \mu \mathrm{g} / \mathrm{cm}^{2}$, which 
Table 1: Titanium and iron surface density values and respective standard deviation for the eye shadows samples analyzed. Letters A, B and C stand for different trademarks.

\begin{tabular}{cccccc}
\hline Sample & $\begin{array}{c}T_{i} \text { surface density } \\
\left(\mu \mathrm{g} / \mathrm{cm}^{2}\right)\end{array}$ & $\begin{array}{c}F_{e} \text { surface density } \\
\left(\mu \mathrm{g} / \mathrm{cm}^{2}\right)\end{array}$ & $\begin{array}{c}\text { Sample } \\
T_{i} \text { surface density } \\
\left(\mu \mathrm{g} / \mathrm{cm}^{2}\right)\end{array}$ & $\begin{array}{c}F_{e} \text { surface density } \\
\left(\mu \mathrm{g} / \mathrm{cm}^{2}\right)\end{array}$ \\
\hline A01 & $30.80 \pm 0.47$ & $16.03 \pm 0.16$ & B05 & $17.06 \pm 0.30$ & $1.80 \pm 0.07$ \\
A02 & $123.41 \pm 0.67$ & $17.18 \pm 0.17$ & B06 & $8.31 \pm 0.22$ & $11.95 \pm 0.12$ \\
A03 & $8.05 \pm 0.39$ & $47.17 \pm 0.24$ & B07 & $11.76 \pm 0.25$ & $7.26 \pm 0.10$ \\
A04 & $18.27 \pm 0.41$ & $63.28 \pm 0.27$ & B08 & $25.50 \pm 0.33$ & $3.54 \pm 0.08$ \\
A05 & $47.94 \pm 0.49$ & $11.19 \pm 0.15$ & B09 & $38.32 \pm 0.36$ & $3.15 \pm 0.08$ \\
A06 & $77.27 \pm 0.53$ & $11.62 \pm 0.15$ & B10 & $14.55 \pm 0.27$ & $2.51 \pm 0.07$ \\
A07 & $69.61 \pm 0.55$ & $17.90 \pm 0.16$ & C01 & $47.88 \pm 0.43$ & $11.08 \pm 0.27$ \\
A08 & $26.49 \pm 0.42$ & $7.53 \pm 0.13$ & C02 & $9.28 \pm 0.24$ & $4.23 \pm 0.09$ \\
A09 & $45.11 \pm 0.47$ & $17.25 \pm 0.16$ & C03 & $10.55 \pm 0.25$ & $4.41 \pm 0.09$ \\
A10 & $66.72 \pm 0.51$ & $19.58 \pm 0.16$ & C04 & $40.99 \pm 0.39$ & $7.66 \pm 0.25$ \\
A11 & $51.77 \pm 0.41$ & $15.12 \pm 0.13$ & C05 & $45.65 \pm 0.41$ & $4.49 \pm 0.19$ \\
A12 & $27.06 \pm 0.33$ & $6.05 \pm 0.09$ & C06 & $26.42 \pm 0.32$ & $6.30 \pm 0.10$ \\
A13 & $64.34 \pm 0.50$ & $66.92 \pm 0.25$ & C07 & $33.94 \pm 0.35$ & $19.98 \pm 0.14$ \\
A14 & $23.97 \pm 0.34$ & $198.16 \pm 0.40$ & C08 & $20.35 \pm 0.30$ & $4.87 \pm 0.09$ \\
B01 & $19.86 \pm 0.31$ & $2.30 \pm 0.07$ & C09 & $9.70 \pm 0.25$ & $77.57 \pm 1.06$ \\
B02 & $24.13 \pm 0.33$ & $4.42 \pm 0.09$ & C10 & $9.74 \pm 0.24$ & $47.39 \pm 0.21$ \\
B03 & $10.81 \pm 0.27$ & $1.48 \pm 0.07$ & C11 & $7.77 \pm 0.23$ & $58.36 \pm 0.23$ \\
B04 & $13.94 \pm 0.29$ & $1.82 \pm 0.07$ & C12 & $10.46 \pm 0.24$ & $39.12 \pm 0.19$ \\
\hline
\end{tabular}

Source: The Author.

is black due to iron oxide that is commonly used in eye shadows.

Samples A12 and B09, both blue, have different amounts of titanium and iron. Sample A12 has a darker tone due to fewer amount of iron, while sample B09, with more titanium, has a lighter shade.

Even for black eye shadows the difference among trademarks remains, i. é., sample A14 has a huge amount of iron and on the other side sample B07 has a smaller amount of iron than titanium.

The ratio between titanium surface density and the iron surface density for trademark A samples are presented in figure 4.

Figure 4 shows that samples from A05 to A12, except A06, have the titanium/iron ratio around 4, while for sample A13 it's around 1. Samples A03, A04 and A14 stand out due to their low titanium/iron ratio, which grants a darker shade to their colors. For samples A02 and A06, the great titanium surface density grants them a lighter shade.

Figure 5 shows the tendency of the titanium/iron ratios for trademark B to be around 8, except for samples B06 and B07, which have great amount of iron compared with
Figure 4: Titanium/iron ratios for trademark A samples.

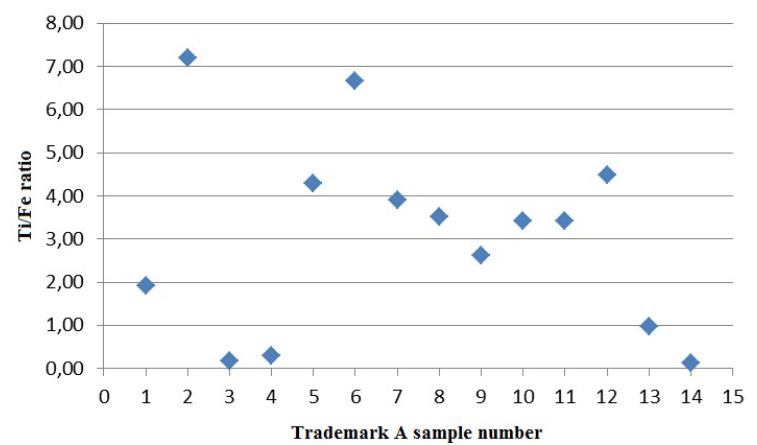

Source: The author.

the same trademark eye shadows, this is due to the usage of iron oxide as a black pigment.

Figure 6 shows that samples from C01 to C08, except $\mathrm{C} 05$, have a titanium/iron ratio around 4 . While samples C05 presents a great titanium/iron ratio, that grants the light shade to the eye shadow, as well as sample A06, both purple.

Other elements, beside titanium and iron, were found in the eye shadow samples and are shown in table 2.

Although some chromium compounds are allowed, the chromium quantity shall not be greater than 5 ppm 
Table 2: Samples with elements other than titanium and iron. Intensity and respective standard deviation presented are in counts per seconds (cps). For comparison purposes, also titanium and iron intensity are presented.

\begin{tabular}{ccccccc}
\hline Sample & $\mathrm{Mn}(\mathrm{cps})$ & $\mathrm{Cr}(\mathrm{cps})$ & $\mathrm{Cu}(\mathrm{cps})$ & $\mathrm{Zn}(\mathrm{cps})$ & $T_{i}(\mathrm{cps})$ & $F_{e}(\mathrm{cps})$ \\
\hline $\mathrm{A} 13$ & - & $3.63 \pm 0.09$ & - & - & $20.01 \pm 0.15$ & $59.71 \pm 0.22$ \\
B09 & - & - & $0.97 \pm 0.07$ & $1.40 \pm 0.08$ & $11.92 \pm 0.11$ & $2.81 \pm 0.07$ \\
C01 & $20.42 \pm 0.14$ & - & - & - & $14.89 \pm 0.13$ & $9.88 \pm 0.24$ \\
C04 & $8.61 \pm 0.10$ & - & - & - & $12.75 \pm 0.12$ & $6.83 \pm 0.22$ \\
C05 & $15.61 \pm 0.12$ & - & - & - & $14.20 \pm 0.13$ & $4.00 \pm 0.16$ \\
C09 & $7.17 \pm 0.10$ & - & - & - & $3.01 \pm 0.08$ & $69.21 \pm 0.94$ \\
\hline
\end{tabular}

Source: The Author.

Figure 5: Titanium/iron ratios for trademark B samples.

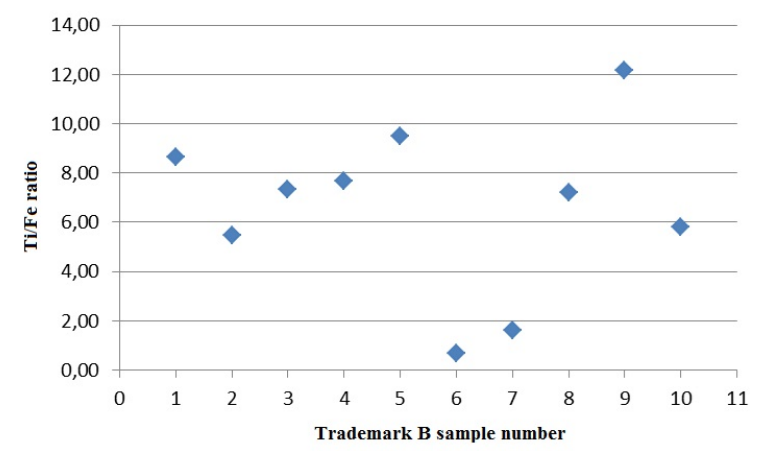

Fonte: the author.

Figure 6: Titanium/iron ratios for trademark A samples.

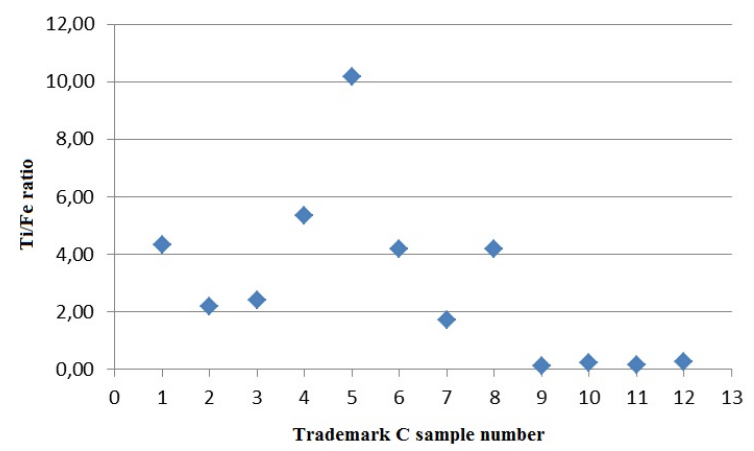

Source: The author.

(BASKETTER, D. A. et al., 2003; CORAZZA, M. et al., 2009). Quantification of this element was not possible due to the lack of chromium standards at our laboratory. Manganese, copper and zinc found in samples B09, C01, C05 and C09 were also measured in eye shadows bought in Nigeria and produced in China (OMOLAOYE, J. A. et al., 2010).

The surface density values for titanium and iron for the blush samples, calculated through the equations (2) and (3), respectively, are shown in table 3. Titanium/iron ratios for all blush samples are presented in figure 7 .
Table 3: Surface density values for titanium and iron for the analyzed blush samples. Letters A, B and C stand for different trademarks.

\begin{tabular}{ccc}
\hline Sample & $\begin{array}{c}T_{i} \text { surface density } \\
\left(\mu \mathrm{g} / \mathrm{cm}^{2}\right)\end{array}$ & $\begin{array}{c}F_{e} \text { surface density } \\
\left(\mu \mathrm{g} / \mathrm{cm}^{2}\right)\end{array}$ \\
\hline bA1 & $48.68 \pm 0.41$ & $22.37 \pm 0.15$ \\
bA2 & $29.51 \pm 0.34$ & $39.84 \pm 0.19$ \\
bA3 & $3.88 \pm 0.19$ & $27.59 \pm 0.16$ \\
bA4 & $2.75 \pm 0.17$ & $4.84 \pm 0.09$ \\
bB1 & $19.08 \pm 0.29$ & $9.63 \pm 0.11$ \\
bC1 & $5.54 \pm 0.20$ & $9.48 \pm 0.11$ \\
bC2 & $1.76 \pm 0.16$ & $26.34 \pm 0.16$ \\
\hline
\end{tabular}

Source: The Author.

Figure 7: Titanium/iron ratios for blush samples.

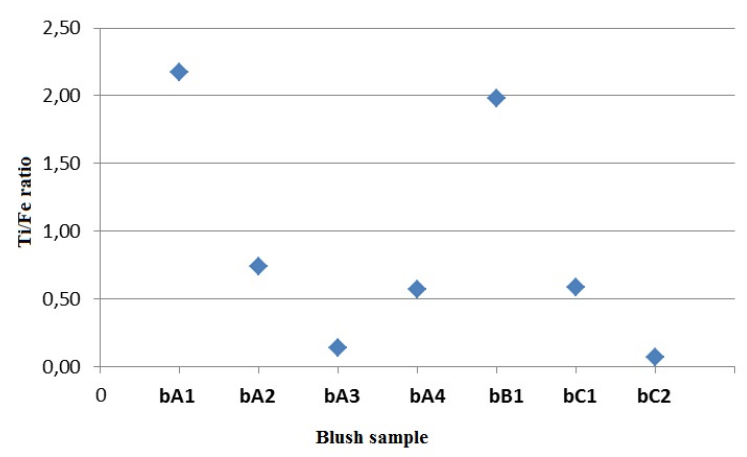

Source: The author.

It is visible from table 3 and figure 7 that the analyzed blushes have a greater quantity of iron than titanium, except for samples bA1 and bB1, in which the titanium quantity is twice that of iron. 


\section{Conclusions}

The methodology has great potential for identification and quantification of chemical elements, especially metals, in eye shadow and blush samples.

One of the advantages of this methodology is the possibility of analyzing samples without any preparation, in a non-destructive manner.

It was determined the surface density of titanium and iron, as well as the titanium/iron ratio, present in 36 eye shadow samples and 7 blush samples of 3 different trademarks. It was verified the use of titanium for lighter shades and the use of iron for darker shades. It was measured the variation in titanium and iron quantities in eye shadows and blushes with same color but different trademarks.

It was also verified the behavior of titanium/iron ratio among several colors of the same trademark.

Other elements were also detected, such as $\mathrm{Mn}, \mathrm{Cr}, \mathrm{Cu}$ and $\mathrm{Zn}$, which may represent a health risk at some level and should be carefully investigated.

\section{Acknowledgements}

The authors thank $\mathrm{CNPq}$ for the financial support, which made this work possible.

\section{References}

Operating manual: XR100CR X-ray detector system and PX2CR. Bedford, MA: Power Supply, 1998.

AGÊNCIA NACIONAL DE VIGILÂNCIA SANITÁRIA - ANVISA. Resolução No 79/2000. Regulamento da ANVISA aprovado pelo Decreto 3.029, de 16 de abril de 1.999. Diário Oficial da União, Brasília, 31 ago. 2000.

ATZ, V. L. Desenvolvimento de métodos para determinação de elementos traço em sombra para área dos olhos e batom. 2008. 75 f. Dissertação (Mestrado em Química) Universidade Federal do Rio Grande do Sul, Rio Grande do Sul. 2008.

BASKETTER, D. A.; ANGELINI, G.; INGBER, A.; KERN, P. S.; MENNÉ, T. Nickel, chromium and cobalt in consumer products: revisiting safe levels in the new millennium. Contact Dermatitis, Copenhagen, v. 49, p. 1-7, 2003. https://doi .org/10.1111/j.0105-1873. $2003.00149 . x$.

CORAZZA, M.; BALDO, F.; PAGNONI, A.; MISCIOSCIA, R. VIRGILI, A. Measurement of nickel, cobalt and chromium in toy make-up by atomic absorption spectroscopy. Acta Dermato-Venereologica, Stockholm, v. 89, p.13-133, 2009. https://doi.org/10.2340/ 00015555-0595.

KUMAR, S. Exploratory analysis of global cosmetic industry: major players, technology and market trends. Technovation, Sheffield, v. 25, n. 11, p. 1263-1272, 2005. https://doi.org/10.1016/j.technovation. 2004.07 .003$.

MOXTEK Inc., Operatin Manual: miniature bullet X-ray tube, Bedford, 2003.

OMOLAOYE, J. A.; UZAIRU, A.; GIMBA, C. E. Heavy metal assessment of some eye shadow products imported into Nigeria from China. Archives of Applied Science Research, Mmabatho, v.5, p. 76-84, 2010.

U.S. GOVERNMENT PRINTING OFFICE. Food and drugs: listing of color additives exempt from certification (Part 73). In: Electronic Code of Federal Regulations (e-CFR). 2014. Available from internet: http: //www. ecfr.gov/cgi-bin/text-idx?c= ecfr\&SID=0f 29870bbaf c6ae3d1efc78d9927d918\& tpl=/ecfrbrowse/Title21/21cfr73_main_02.tpl. Acess in: May 15, 2017.

VAN GRIEKEN, R. E.; MARKOWICZ, A. A., Handbook of $X$-ray spectrometry. 2. ed. New York: Marcel Dekker Inc, 2002. 